\title{
Statement of Principle
}

Published online: 20 November 2014

(C) the Endocrine Society 2014

We, as representatives of scientific organizations devoted to improving health care and advancing research, reaffirm that it is the mission of our respective medical journals to report and disseminate data from scientific investigation, evolving medical care, and innovative treatments. We believe these reports serve to unite basic scientists, clinical investigators, and medical professionals regardless of their country of origin, ethnic group, or political leaning. We believe that these efforts achieve the common goal of advancing scientific discoveries that lead to improved health of people worldwide. On the basis of our goals and principles, our respective journals will refrain from publishing articles addressing political issues that are outside of either research funding or health care delivery.

William T. Cefalu, MD, Editor in Chief, Diabetes Care K. Sreekumaran Nair, MD, PhD, Editor in Chief, Diabetes Elizabeth R. Seaquist, MD, President, Medicine and Science, American Diabetes Association
Juleen Zierath, PhD, Editor in Chief, Diabetologia Andrew J.M. Boulton, MD, President, European Association for the Study of Diabetes

Derek LeRoith, MD, PhD, Editor in Chief, Endocrine Practice

R. Mack Harrell, MD, President, American Association of Clinical Endocrinologists

George Grunberger, MD, President Elect, American Association of Clinical Endocrinologists

Leonard Wartofsky, MD, Editor in Chief, The Journal of Clinical Endocrinology and Metabolism

Andrea C. Gore, PhD, Editor in Chief, Endocrinology

Margaret E. Wierman, MD, Acting Editor in Chief, Endocrine Reviews

Stephen R. Hammes, MD, PhD, Editor in Chief, Molecular Endocrinology

Carol A. Lange, PhD, Editor in Chief, Hormones and Cancer Richard J. Santen, MD, President, Endocrine Society 